\title{
More on Search Warrants, Good Faith, and Probable Cause
}

\section{Donald Dripps†}

I am gratified that Professor Duke considers my analysis of the goodfaith exception to the exclusionary rule in warrant cases ${ }^{1}$ sufficiently important ("pernicious" and "destructive" are his actual words) not to go without a vigorous rebuttal. ${ }^{2}$ I am, however, unpersuaded by his position, which has more wrong with it than the failure to refute my own.

\section{The Nature of the Warrant Process}

Professor Duke and I offer competing accounts of the warrant process. I believe that police apply for search warrants because they seek admissible evidence, that warrants are more costly than investigative alternatives, and that therefore the police rarely seek warrants without probable cause. He believes that the police obtain warrants without anything approaching probable cause, ${ }^{\mathbf{3}}$ that warrant searches are unreliable, and that judicial hostility and defense neglect have nullified the exclusionary rule. ${ }^{6}$ Which account is more consistent with the evidence?

$I$ argue that the low suppression rate and the success rate of warrant searches indicates reliability. Professor Duke responds that the low suppression rate results from systemic hostility to the Fourth Amendment, and that the seizure statistics are inflated by the police and inconsistent with the conviction data. ${ }^{7}$ The low suppression rate holds, however, independently of the frequency of suppression motions. ${ }^{8}$ It holds also in liberal jurisdictions, such as the D.C. Circuit ${ }^{9}$ and pre-proposition 8 Califor-

+ Assistant Professor, University of Illinois, College of Law.

1. Dripps, Living With Leon, 95 Yale L.J. 906 (1986).

2. Duke, Making Leon Worse, 95 Yale L.J. 1405 (1986).

3. Id. at 1413 .

4. Id. at $1409-13$.

5. Id. at $1413-15$.

6. Id. at $1406-09$.

7. Id. at $1409-13$.

8. See R. Van Duizend, L. Sutton \& C. Carter, The Search Warrant Process: Preconceptions, Perceptions, and Practices 57 (1984) [hereinafter cited at NCSC STUdy]. In six of the seven jurisdictions studied, the frequency of suppression motions in warrant cases ranged from $7 \%$ to $57 \%$, but cases in which a motion was granted ranged only from 0 to $2 \%$. In the seventh jurisdiction, motions were made in $45 \%$, and granted in $11 \%$, of the cases. See also Nardull, The Societal Costs of the Exclusionary Rule: An Empirical Assessment, 1983 A.B.F. REs. J. 585, 598.

9. See Wasserstrom \& Mertens, The Exclusionary Rule on the Scaffold: But Was It a Fair Trial?, 22 AM. CRIM. L. Rev. 85, 103 (1984). 
nia. ${ }^{10}$ The California record is particularly interesting, because that state did not follow the more notorious Burger Court exclusionary rule decisions. ${ }^{11}$

Professor Duke claims that the police go to the trouble of seizing innocuous items and filing returns to protect the reliability of informants. But the NCSC study concludes that "[i]n an average of $91 \%$ of the executed warrants, at least some seizure was made, and in an average of $74 \%$ of those warrants, the officers seized all or most of the items seized."12 Of the seizures, $48 \%$ included narcotics and paraphernalia, 34\% stolen goods, and $23 \%$ weapons. ${ }^{13}$ Nor can Professor Duke explain why the police care about informant reliability, since he does not believe the exclusionary rule deters or that warrant applications receive any serious scrutiny. The notion that cash and weapons are inappropriate targets of a search, in a society with drug laws, speaks for itself.

10. Davies, A Hard Look at What We Know (and Still Need to Learn) About the "Costs" of the Exclusionary Rule: The NIJ Study and Other Studies of Lost Arrests, 1983 A.B.F. RES. J. 577, 653 (for 1976-79, exclusionary rule led to loss of only $0.9 \%$ of California felony arrests). California is generally recognized as a liberal jurisdiction, see Abrahamson, Criminal Law and State Constitttions: The Emergence of State Constitutional Law, 63 TEx. L. REv. 1141, 1181 n.162 (1985), and the truth-in-evidence amendment to the state's constitution was not adopted until 1982. In re Lance W., 210 Cal. Rept 531, 634, 694 P.2d 744, 747 (1985).

Professor Duke argues also that warrant accuracy is belied by the facts that convictions often occur in cases involving successful suppression motions and that successful motions occur more frequently in warrant than in warrantless cases. Duke, supra note 2, at $1409,1412 \mathrm{n} .58$. The standing requirement of itself could explain the first phenomenon. Moreover, to the extent that the prosecution can prove guilt beyond a reasonable doubt, probable cause for the search could have been established as well. The second fact is explained by the ubiquity of Fourth Amendment issues in warrant cases; the vast bulk of searches incident to arrest yield nothing of evidentiary value. Compare NCSC STuDY, supra note 8 , at 57 (motion to suppress filed in 149, or $43 \%$, or 347 warrant cases) with Nardulli, supra note 8, at 595 (motions to suppress physical evidence filed in $4.6 \%$ of all cases studied).

11. See Kaplan v. Superior Court, 6 Cal. 3d 150, 98 Cal. Rptr. 649, 491 P.2d 1 (1971) (reaffirming vicarious exclusionary rule); People v. Moore, 69 Cal.2d 674, 72 Cal. Rptr. 800, 446 P.2d 800 (1968) (exclusionary rule applies in quasi-criminal civil proceedings); People v. Taylor, $8 \mathrm{Cal}$. 3d 174, 104 Cal. Rptr. 350, 501 P.2d 918 (1972) (en banc) (tainted evidence admissible for impeachment only when defendant makes sweeping denial of any narcotics involvement). Taylor was decided prior to United States v. Havens, 446 U.S. 620 (1980), and rested on federal grounds. But the California courts continued to apply the Taylor rule after Havens was decided. See People v. Flores, $128 \mathrm{Cal}$. App. 3d 512, 522-23, 180 Cal. Rptr. 368, 374 (Super. Ct. 1982).

12. See NCSC STUDY, supra note 8, at 95-96. A fair reading of the study puts the practice of protecting informant reliability in perspective:

These averages may be somewhat inflated. As suggested above, when time is of the essence, searches are conducted under one of the exceptions to the warrant requirement. Moreover, these figures are affected by failures to file a return when nothing is seized, and by the practice described to us by a Plains City detective of seizing something, even if it is only identification, to protect the "reliability" of an informant. But, it should be noted that there was general agreement among the police officers to whom we spoke that "bloop warrants" (Harbor City) or "dry holes" (Plains City) are few.

Id. (footnote omitted). In my original article, I adjusted the seizure statistics by conservatively assuming that none of the unreturned warrants was successful. See Dripps, supra note 1, at 925 \& n.115. Also, in some cases evidence may exist but successfully be hidden or destroyed. See NCSC STUDY, supra note 8, at 52; see also Dripps, supra note 1, at 925 n.118, 928 n.126 (discussing wiretap evidence and Rebell's study).

13. NCSC STUDY, supra note 8, at 53. 
Professor Duke stresses the relative infrequency of prosecutions brought in warrant cases found by the NCSC study. ${ }^{14}$ This finding might reflect the unreliability of warrant searches, but the rate of seizures suggests that the explanation lies elsewhere. The NCSC study itself cautions that the statistics on the filing of charges are conservative, because of the difficulty of identifying subsequent prosecutions. ${ }^{15}$ Given the difficulty of identifying subsequent prosecutions even in the same jurisdiction, and the frequency of referrals to other jurisdictions for prosecutions, ${ }^{18}$ the NCSC figures on cases filed probably underestimate the true numbers substantially.

Seizures may not lead to prosecutions for a variety of reasons. The object of the search may not be conviction but simple seizure of contraband, a perfectly constitutional practice given probable cause. ${ }^{17}$ The government may not be able to link any individual to the evidence seized. ${ }^{18}$ Individuals they can link to the search fruits may not tarry for arrest. Prosecutorial screening may reject provable cases, based on information not available before the search. ${ }^{19}$ Even when police recover physical evidence, convictions result less than half of the time. ${ }^{20}$ For example, in one study, the police recovered tangible evidence in $88 \%$ of nearly 2,000 drug arrests, but convictions occurred in only $24 \%$ of the cases. ${ }^{21}$.

Thus, the seizure rate, rather than the prosecution or conviction rate, offers the fairest measure of search warrant accuracy. It is nonetheless interesting to note that for warrants on which good records are kept and which are not aimed at simple seizure of contraband, convictions result in a large proportion of cases. I refer to warrants authorizing electronic sur-

14. Duke, supra note 8 , at 1411-12.

15. NCSC STUDY, supra note 8, at 54-55 ("Retrieval of information about whether a criminal case ever evolved from an issued warrant constituted, without a doubt, the most taxing and troublesome aspect of our data collection effort."). In the one jurisdiction studied intensively, the NCSC researchers found that charges were filed in $83 \%$ of the warrant cases. The authors attribute this to the practice in that jurisdiction of not filing a return when the search was unsuccessful; but, again, I adjusted the seizure statistics for nonreturn warrants in my original paper. If $83 \%$ of successful warrants lead to prosecutions, then in the other six jurisdictions the percentage of warrants leading to prosecution would range from $61 \%$ to $74 \%$. See Dripps, supra note 1, at 925 n.115.

16. See K. Brosi, A Gross-City Comparison of Felony Case Processing 16 (1979) (in study of five cities, referrals to other prosecutors accounted for from a low of $1 \%$ (District of Columbia) to a high of $37 \%$ (Los Angeles) of cases rejected by prosecutors before filing formal charges).

17. See NCSC STUDY, supra note 8 , at 55 .

18. Id.

19. Id. (" $[\mathrm{P}]$ rosecutorial screening was intense in most of the jurisdictions, so that many police investigations did not result in formal prosecution."). It is true that prosecutors also screen warrant applications, but the focus at that stage is probably quite distinct. The prosecutor screening a warrant is asked to help support the probable cause showing, not to tell the police what crimes to investigate. Subsequently, a (probably different) prosecutor, knowing the witnesses, the background of the defendant, and other prosecutorial priorities, must make the very different decision to file charges.

20. See B. Forst, J. Lucianovic \& S. Cox, What Happens After ArRest?: A Court Perspective of Police Operation in the District of Columbia exhibit 3.11 , at 29 (1977).

21. Id. exhibit 3.14 , at 31 . 
veillance; in the period 1978-1982, for example, 2697 electronic surveillance orders led to 7,233 convictions. ${ }^{22}$ Some wiretaps lead to dozens of convictions, so the conviction rate is a little harder to estimate. But following up wiretap orders for several years reveals that about half of the warrants issued led to convictions. ${ }^{23}$

I argue that the relative cost of warrants explains their surprising success. Professor Duke counters with the assertion that warrantless police techniques, such as arresting the defendant, impose much higher costs on the police but do not evidence probable cause. ${ }^{24}$ His analysis fails to recognize that costs influence behavior only in relation to perceived returns. ${ }^{25}$ Since arrests are a primary object of police activity, the costs of arrest are irreducible relative to law enforcement return. Nor do the police who might invade privacy incur the bulk of the costs of arrest, which falls on other actors in the system. Professor Duke's claim is analogous to the suggestion that the sales division of a private firm would abandon its efforts because success imposes on the accounting division the cost of collecting bills.

The marginal cost of a police technique therefore excludes the cost of arrest. The marginal cost of a warrant includes the investigation necessary to satisfy the issuing judge that probable cause exists, ${ }^{28}$ the drafting and review of the application, and the execution of the search. Warrantless searches incur only this final cost. Since the reliability of warrants depends in part on their cost, reducing the cost of warrants would encourage their use only at the sacrifice of the purpose of encouraging warrants. Similarly, warrantless techniques are legitimate precisely because they are

22. See Administrative Office of the U.S. Courts, Report on Applications for ORDERS AUTHORIZING OR APPROVING THE INTERCEPTION OF WIRE OR ORAL COMMUNICATIONS (Wiretap Report) For the Period January 1, 1985 to December 31, 1985, table 9, at 25 (1986).

23. In 1981, federal judges issued 106 electronic surveillance orders. The supplementary reports contained in Appendix Table A-2 of the annual Administrative Office Reports through 1985 reveal that 57 of these, or $54 \%$, led to convictions. For 1982, 58 of 130 orders led to convictions by the end of 1985 , for a $45 \%$ record. The 1986 Report may well document additional convictions for both years.

These figures are not atypical. See Shieber, Electronic Surveillance, the Mafia, and Individual Freedom, 42 LA. L. REv. 1324, 1359 (1982) (as of 1980, $42 \%$ of all federal electronic surveillance orders led to convictions). Since these figures do not include convictions rendered later than 1980, Professor Shieber's total is a substantial underestimate. The 1981 Report, for example, reports new convictions resulting from 23 wiretaps authorized during the 1969-1979 period. Professor Duke concedes that evidence "indicating that warrant searches usually result in the seizure of highly incriminating evidence that is causally related to a criminal charge, or, better, to a conviction" would provide "some interesting data." Duke, supra note 2 , at 1412.

24. Duke, supra note 2, at 1416-17.

25. See, e.g., J. Hirshleifer, Price Theory and Applications 288 (2d ed. 1980).

26. Professor Duke is correct that some police investigation goes forward before the police know whether they will seek a warrant, but the decision to seek a warrant entails additional investigation. An officer will not go to a prosecutor and a judge on the basis of the same minimal suspicion that might induce dropping by the suspect's abode and asking for consent to search. 
less costly than warrants and in appropriate circumstances (probable cause or valid consent) do not unjustifiably intrude on privacy. Increasing the cost of warrantless searches would defeat their purpose. Unlike warrant searches, in these cases there is neither a judicial determination of probable cause nor independent circumstances discouraging searching without probable cause. Thus, from the standpoint of a systemic compromise between privacy and law enforcement, it makes sense to regulate warrant searches by maintaining their relative cost, and to regulate warrantless searches by limiting their relative return.

Professor Duke makes the plausible argument that an extensive but so far futile police investigation suggests the innocence of the target but would, in my approach, figure in the justification of a warrant. But though that cost is fixed, why would the police then incur the marginal cost of the warrant procedure? No warrant is required for harassment, ${ }^{27}$ so Professor Duke's scenario makes sense only if warrant searches offer poor prospects for a good arrest, and if no investigative alternative is even that promising. If this is the typical search warrant situation, the figures for successful seizures, cases filed, and convictions are inexplicably high.

Indeed, in Professor Duke's view, everything about warrants is inexplicable. He does not believe that exclusion or the damage remedy exerts a perceptible deterrent effect, ${ }^{28}$ so he cannot explain why the police ever seek warrants. He does not believe that cost or preapplication screening discourages unsound warrant applications, so he cannot explain why warrants are even as successful as his interpretation of the evidence admits. ${ }^{29}$ Yet he is not alone in his preconceptions about search warrants; ${ }^{30}$ in my view, the confounding of familiar doctrine by the available empirical evidence indicates the need to rethink the prevailing wisdom.

\section{The Nature of Probable Gause}

In contrast, Professor Duke follows his extensive review of the empirical evidence with the announcement that he holds his position without regard to the empirical evidence. ${ }^{31} \mathrm{He}$ argues that the procedural approach to probable cause I advocate involves a mathematicist legal theory which is both impractical and destructive of constitutional rights. ${ }^{32}$ Yet he

27. Under Briggs v. Malloy, 106 S. Ct. 1092 (1986), a warrant confers damage immunity no broader than admissibility of evidence under Leon.

28. Duke, supra note 2, at 1413-15.

29. Id. at 1418-20.

30. See, e.g., sources cited in Dripps, supra note 1, at 929 n.127.

31. Duke, supra note 2 , at 1421 .

32. Id. at 1420-22. I have borrowed the "mathematicist" adjective from L. CoHEN, THE ProbABLE AND THE Provable (1977). The usual critique of probabilistic evidentiary rules holds that such rules involve intractable paradoxes and conjunction problems. An example of the former difficulty is 
also maintains that probable cause is an essentially mathematical concept. $^{33}$ I believe that his objection does not apply to my analysis with any force, but is rather emphatically invited by his own position.

I thought I had made clear that the approach I defend would not "nullify the warrant clause, but only acknowledge that the probable cause standard is primarily directed to issuing judges rather than reviewing courts." ${ }^{\text {34 }}$ The issuing judge, who plays a role in the warrant process, cannot look to that process for guidance. She should apply a substantive standard to the warrant application. Current law describes the substantive standard as "more probable than not" under some circumstances, and as "somewhat less than more probable than not" under other circumstance. ${ }^{35}$ The degree of probability is determined not by a wooden application of the constitutional language, but by a pragmatic assessment of the competing values of liberty and law enforcement. ${ }^{36} \mathrm{My}$ approach would not change the substantive standard, but instead would alter the procedure for determining when that standard is satisfied.

If Professor Duke is correct that this transformation would imperil constitutional values, his argument comes too late. The criminal process includes a host of procedures deemed conclusive of particular issues. The issuance of an arrest warrant or an indictment is conclusive of probable cause to detain a suspect. ${ }^{37}$ The jury's verdict of conviction is conclusive unless irrational. ${ }^{\text {s8 }} \mathrm{A}$ myriad of trial court determinations bearing on the defendant's guilt or innocence and the sentence due the guilty are reversible only for abuse of discretion. Such arrangements are inevitable as well as commonplace; at some point the legal process must achieve finality. In Professor Duke's approach, for example, probable cause is whatever the court of last resort says it is.

I would condition the unreviewability of search warrants on executive screening practices, but current law incorporates similar rules. The indictment cases involve the parallel judgment that a particular executive-

the "blue bus hypothetical." If a defendant owns $80 \%$ of the blue busses in a community, and a plaintiff is injured by a blue bus, it is more likely than not that defendant is liable. But this approach would make the defendant liable for every accident involving a blue bus. See Tribe, Trial by Mathematics: Precision and Ritual in the Legal Process, 84 Harv. L. Rev. 1329, 1349-50 (1971). The conjunction problem is exemplified by the case of the plaintiff who can prove that all three elements of her case are more probable than not, but as a result her case considered as a whole is less likely than not. See L. CoHEN, supra, at 58-67.

33. Duke, supra note 2 , at 1418 n.100.

34. Dripps, supra note 1 , at 941-42.

35. See sources cited id. at 925 n.116.

36. See 1 W. LaFave, Search and Seizure: a Treatise on the Fourth amendment $\S$ 3.2(E) (1978 \& 1986 Supp.); Grano, Probable Cause and Common Sense; a Reply to the Critics of Illinois v. Gates, 17 U. MICH. J.L. ReF. 465, 495-501 (1984).

37. See Dripps, supra note 1 , at 942.

38. Jackson v. Virginia, 443 U.S. 307 (1979). 
dominated procedure is dispositive of probable cause. The courts similarly have held that executive expertise in detecting crime should be accounted for in the probable cause determination. ${ }^{39}$ If there is a slippery slope, we have been on it for a long time.

But the commission of particular issues to conclusive procedures does not entail application of mathematicist jurisprudence. That a jury verdict is conclusive of guilt because juries in general make wise decisions about guilt does not mean that the jury is to apply a rigid mathematical standard. Just so, I do not suggest that issuing judges defer to executive investigation because investigation and screening correlate with success; the issuing judge is, as I hoped to make clear originally, a part of the process to which reviewing courts should defer. ${ }^{40}$

In contrast, Professor Duke's analysis of probable cause invites all the dangers and paradoxes of probablistic jurisprudence. In his view, "[t]he Fourth Amendment requires a showing of probable cause to believe that a specified crime has been committed, that specified contraband, instrumentalities or evidence of that crime exists, and that said specified material is located in a specified place." ${ }^{\prime 11}$ This inflexible analysis badly serves either liberty or law enforcement. Suppose the police can prove to a certainty that the suspect is dealing heroin, cocaine or quaaludes from a particular location, but not that any one of these particular crimes is in progress. A search poses no threat to the lawful enjoyment of privacy and would advance the enforcement of the criminal law. ${ }^{\mathbf{2}}$ But if the standard is instead a better than even chance that some crime is in progress at the place to be searched, then just as Professor Duke apprehends, warrants could be issued to search every residence. ${ }^{43}$ Such an approach would guarantee a very large number of searches unjustified in fact. Thus, it is Professor Duke's analysis that most clearly invites the conjunction problems and paradoxes characteristic of mathematicist legal theory. ${ }^{44}$

The procedural approach to probable cause does not, then, reduce the inquiry to a mechanical calculus. Rather, it acknowledges that the variables involved are so numerous that the cases will not be consistently decided. Given that, the law should look to some procedure to strike a reasonable systemic balance between law enforcement and privacy. Empirically demonstrated reliability confirms that the warrant process offers such a procedure. Thus, the procedural approach governs the meaning of probable cause after-and not before-the completion of the war-

39. See 1 W. LAFAve, supra note 36 , at $\S 3.2(\mathrm{c})$.

40. See Dripps, supra note 1, at 941-44.

41. Duke, supra note 2, at 1410 (emphasis in original) (footnote omitted).

42. See $1 \mathrm{~W}$. LAFAVE, supra note 36 , at $\S 3.2(\mathrm{E})$.

43. Duke, supra note 2 , at 1411 n.47.

44. See supra note 32 . 
rant procedure itself. It therefore does not embrace, as does Professor Duke's approach, the defects of probablistic jurisprudence.

As for the important challenge of identifying the reliability of the warrant process over time, ${ }^{45}$ the limited review of warrant searches I endorse could make sure that the process does not deteriorate. Since the warrant procedure would be conclusive absent plain error only so long as independent investigation and screening were undertaken, the defendant could overcome the conclusiveness of the procedure by showing that in her case screening or independent investigation did not occur. ${ }^{46}$ On such a showing, the reviewing court would examine the substantive issue independently. And just as with jury verdicts, a patently unsupportable warrant application could be found unlawful notwithstanding the absence of procedural irregularity. On one hand, the reviewing courts would perform a function they can fulfill, namely, determining the adequacy of the warrant procedure rather than the sufficiency of the affidavit. On the other hand, when the procedure plainly fails in a particular case, that is, when reasonable people could not disagree about the insufficiency of the warrant application, the warrant would fail in any event. Review of this sort would ensure that the warrant process remains as reliable as current information suggests.

\section{The Supreme Court and Its Critics}

Finally, and perhaps most fundamentally, Professor Duke objects to revising the Court's opinions rather than simply protesting them. ${ }^{47}$ If the Court is constitutionally perverse, its decision should be given their most perverse interpretation. Scholarship has the task of Court-trashing, pure and simple.

This assumes, in my view wrongly, that reconstruction erodes the credibility of critique, and that the Court is always wrong because it has reasoned poorly. I do not know how I could more forcefully have condemned the Court's "antipathy to the prohibition of unreasonable searches and seizures." ${ }^{148}$ It is precisely in the nakedness of that antipathy that Leon differs from the Court's prior cases. Professor Duke sees no difference because he was willing to look through the Court's opinions all along. For my part, I am willing to give the Justices the benefit of the doubt, a

45. See Duke, supra note 2 , at 1422 n.112.

46. This is scarcely an impossible inquiry. In two jurisdictions, the NCSC researchers found that issuing judges expected applications to carry a prosecutor's initials. See NCSC STUDY, supra note 8, at 25. Independent investigation or its absence will be clear from the face of the application.

47. See Duke, supra note 2, at 1422-23.

48. Dripps, supra note 1 , at 948 . 
benefit forfeited at last by the open anticonstitutionalism of decisions like Leon. ${ }^{49}$

Beyond the notion that we should take the Court at face value, so long as it faces us, is the unpleasant truism that we start from where we are. The Court's rulings have gradual rather than catastrophic consequences both for individual liberty and for the institutional integrity of the judiciary. ${ }^{50}$ My reformulation of Leon might prevent only a few more arbitrary searches, and restore only a measure of the Court's credibility. For me that is enough to justify the revision.

On a larger scale, Professor Duke's vision of constitutionalism and the Fourth Amendment is closer to mine than is the Court's. His views may, in time, prevail, but not before a different kind of scholarship arrests the pendulum of informed opinion, and impels it again on the long arc back toward law.

49. Cf. L. HANd, The SPIRIt OF Liberty 109-10 (1952).

50. Professor Duke's apocalyptic description of the effect of the Court's rulings have had on the exclusionary rule's deterrent incentive, for example, is contradicted by the evidence showing that the level of illegal searches (as measured by successful suppression motions) is comparable between jurisdictions following the Court and those that have declined to create exceptions to the exclusionary rule. See supra notes $10-11$. 